\title{
LEI DE DIRETRIZES E BASES E A COMUNICAÇÃO NO SISTEMA DE ENSINO
}

\section{Os meios de comunicação e o domínio das formas contemporâneas de linguagem são assuntos da Educação}

As profundas modificações introduzidas pelo Senado Federal, em fevereiro de 1996, no texto do projeto de Lei de Diretrizes e Bases da Educação Nacional - LDB aprovada, em primeira instância, pela Câmara dos Deputados, provocou muita apreensão junto aos especialistas das diversas áreas ligadas ao estudo da inter-relação Comunicação/Educação.

Passou-se a lamentar o fato de o novo texto ter excluído os dispositivos que tratavam da educação a distância, do uso das tecnologias no ensino, da reserva de tempo e espaço nos meios massivos para projetos $\mathrm{e}$ programas educacionais e da definição de critérios para programas de educação para os meios de comunicação.

Uma leitura atenta da nova proposta permite, contudo, entender que o espírito que ancorava a proposta da Câmara permaneceu, ainda que sem a mesma clareza, na emenda do Senado. É o que se pode deduzir da simples leitura de alguns dos seus artigos, voltados, em síntese, para garantir:

- a capacitação dos estudantes para a análise crítica do mundo e dos fatos que nele ocorrem;

- o desenvolvimento das habilidades de comunicação;
- a autonomia intelectual do educando, preparando-o para o exercício da cidadania plena.

Os artigos da emenda do Senado que tratam do assunto são os seguintes:

Art. $2^{\circ}$ - "A educação...tem por finalidade o pleno desenvolvimento do educando, seu preparo para o exercício da cidadania...";

Art. $3^{\circ}-$ "O ensino será ministrado com base nos seguintes princípios:...

II - liberdade de aprender, ensinar, pesquisar e divulgar a cultura, o pensamento, a arte e o saber..."

$\mathrm{X}$ - valorização da experiência extraescolar.

Art. 25. - "Os conteúdos curriculares da educação básica observarão, ainda, as seguintes diretrizes:

I - A difusão de valores fundamentais ao interesse social, aos direitos e deveres dos cidadãos, de respeito ao bem comum e à ordem democrática..."

\section{O AUTOR}

Prof. Dr. Ismar de Oliveira Soares

Coordenador do Núcleo Comunicação e Educação do Departamento de Comunicações e Artes da ECA-USP. Vice-Presidente (regional) do WCME - World Council for Media Education. E-mail: ismar@usp.br 
Art. 30. - "O ensino fundamental... terá como objetivo a formação básica do cidadão, mediante:

II - a compreensão do ambiente natural e social, do sistema político, da tecnologia, das artes e dos valores em que se fundamenta a sociedade;

III - o desenvolvimento da capacidade de aprendizagem, tendo em vista a aquisição de conhecimento e habilidades e a formação de atitudes e valores..."

Art. 32. - "O ensino médio,... terá como finalidades: dadania;

II - a preparação básica para ... a ci-

III - o aprimoramento do educando como pessoa humana, incluindo a formação ética e o desenvolvimento da autonomia intelectual e do pensamento crítico";

Art. 33. - "O currículo do ensino médio observará (...) as seguintes diretrizes:

I - destacará a educação tecnológica básica (...)

II - adotará metodologias de ensino e de avaliação que estimulem a iniciativa dos estudantes.

$\$ 1^{\circ}-$ Os conteúdos (...) serão organizados de tal forma que ao final do ensino médio o educando demonstre:

I-domínio dos princípios científicos e tecnológicos que presidem a produção moderna;

II - conhecimento das formas contemporâneas de linguagem;

III - domínio dos conhecimentos sócio-históricos necessários ao exercício da cidadania.

\section{A ESPECIFICIDADE DA EMENDA DO SENADO}

Para melhor entender o que diferenciou o projeto do Senado da proposta da Câ- mara é necessário considerar que, no texto anterior, previa-se que o sistema nacional de educação deveria incluir obrigatoriamente a "formação de critérios para a leitura crítica dos meios de comunicação", além de estabelecer dispositivos que indicavam a ampliação do uso dos veículos de comunicação em projetos educativos, contemplando até mesmo a obrigatoriedade da designação, por parte das empresas com mais de cem empregados, de salas aparelhadas para a recepção de programas destinados à educação a distância.

O texto do Senado Federal, por pretender-se mais adequado à técnica legislativa, suprimiu dispositivos e exigências explícitas, as quais dariam maior clareza a uma futura regulamentação constitucional.

Ao serem mantidos, contudo, alguns dos princípios que sustentavam a filosofia que presidiu o projeto anterior, presume-se que os ganhos obtidos na proposta da Câmara não se perderam de todo.

No campo específico da educação para a recepção ativa e crítica, entendida como parte essencial da educação para o exercício da cidadania, a filosofia da nova LDB certamente deverá ser confrontada - ao ser efetivada no cotidiano do trabalho educativo - com a prática corrente nas propostas educativas dos países mais adiantados do mundo, onde:

a) a leitura e a recepção crítica dos meios têm sido entendidas como condição prévia para a leitura do mundo e a preparação para a defesa da democracia, a livre expressão do pensamento e o exercício da cidadania;

b) a Comunicação Social tem sido introduzida como conteúdo programático obrigatório nos currículos de países como 
Áustria, Suécia, Dinamarca, Inglaterra, Espanha, Austrália, Suíça, entre tantos outros, visando, além de uma recepção crítica, à formação de habilidades no campo do exercício do processo comunicativo por parte de um número sempre crescente de pessoas;

c) os recursos tecnológicos da Comunicação Social têm sido colocados à disposição do sistema educativo e apropriados por professores e alunos.

Esta rápida visualização do que ocorre no mundo aponta para um dos caminhos que poderá assumir a regulamentação da nova LDB, caso o trabalho seja assumido por especialistas que alcancem compreender a profunda incidência do sistema de comunicação no mundo contemporâneo.

Pode-se concluir que a definição dos dispositivos de que a educação nacional necessita para concretizar os objetivos propostos pela nova Lei, dependerá muito mais da compreensão efetiva do significado dos princípios aprovados do que de disposições explicitadas na lei sobre a aproximação entre o mundo da comunicação e o mundo da educação.

\section{UM CONSELHO MUNDIAL DE EDUCAÇÃO PARA OS MEIOS}

A inter-relação Comunicação Social/Educação tem sido objeto de projetos de intervenção cultural em todo o mundo. $\mathrm{O}$ que significa dizer que há um interesse coletivo apontando para a legitimidade do tema.

Por entender ser urgente a discussão do assunto, um grupo de especialistas criou, em julho de 1996, o World Council for Media Education (Conselho Mundial de Educação para os Meios), uma entidade com sede em Madri, que congrega especialistas e pesquisadores da área de quase todos os continentes, tendo como objetivo primordial legitimar perante a sociedade os esforços dos pioneiros que há décadas têm oferecido seus esforços para implementar o uso e o estudo dos recursos da comunicação pelos educadores, pesquisadores da educação e pelos consumidores dos produtos veiculados pelo sistema de meios.

No Brasil, o Núcleo Comunicação e Educação do Departamento de Comunicações e Artes da ECA/USP vem reafirmando, nas inúmeras discussões que pomove com educadores, comunicadores, membros de governo e representantes da sociedade civil, as seguintes teses:

1. É necessário transformar a leitura crítica dos meios, a educação para a formação de habilidades no campo da educação, assim como a introdução de tecnologias da comunicação em sala de aula, em conteúdos curriculares específicos ou em atividades interdisciplinares no sistema nacional de ensino, levando-se em consideração as circunstâncias e a preparação do corpo docente;

2. É necessário que as Faculdades de Comunicação Social, assim como as de Educação ou Pedagogia, preparem - através de cursos de graduação, especialização ou pós-graduação - profissionais especialmente qualificados para assessorar o sistema de ensino na introdução da Comunicação Social no novo projeto educativo proposto pela LDB.

Nesse sentido, o Departamento de Comunicações e Artes da ECA/USP associouse a professores e estudantes de outras Universidades da América Latina para criar e manter um programa de formação superior em Gestão de Processos Comunicacionais, com condições de atender à demanda, que já se faz notar, de novos profissionais para a área. Uma espécie de "gestor da comunica- 
ção no espaço educativo", ou seja, um profissional a serviço do sistema de ensino, do sistema de meios e de todos os cidadãos interessados na democratização da prática e da pedagogia da comunicação no país.

No momento, o Núcleo de Comunicação e Educação realiza uma ampla pesquisa buscando identificar os especialistas no campo, na tentativa de traçar um perfil das pessoas que trabalham ou desenvolvem pesquisas acadêmicas na área. O objetivo é ampliar

Resumo: A nova Lei de Diretrizes e Bases da Educação - LDB contempla disposiçōes que aproximam a Comunicação Social da Educação, legitimando preocupaçōes no sentido de garantir aos estudantes formação intelectual que Ihes propicie autonomia crítica frente ao mundo editado pelos meios de comunicação.

Palavras-chave: LDB, meios de comunicação, ensino, leitura crítica, educaçăo para a comunicação a base de sustentação dos projetos em desenvolvimento, tornando-os mais visíveis, inclusive para os órgãos que decidem as políticas de educação e de comunicação do país.

Contatos com o Núcleo de Comunicação e Educação podem ser feitos através do endereço: Av. Professor Lúcio Martins Rodrigues, $443-2^{\circ}$ andar - sala 13 - Cidade Universitária - CEP 05508-900. Fone: (011) 818-4081.

Abstract: The new Act on Guidelines and Bases for Education - AGB (Lei de Diretrizes e Bases da Educação - LDB) includes provisions that straighten the relation between Social Communication and Education, legitimizing a concern that students should receive the guarantee that they will have a solid intellectual development which will provide them with critical independence in a world edited by media.

Key-words: AGB, media, Act of Law, education 